\title{
Pelatihan Peningkatan Kualitas SDM Bidang Pariwisata di Desa Wisata
}

\author{
Sri Sulartiningrum ${ }^{1}$, Fifi Nofiyanti ${ }^{*}$ dan Rina Fitriana ${ }^{1}$ \\ ${ }^{1}$ Sekolah Tinggi Pariwisata Trisakti, IKPN Bintaro, Jakarta, Indonesia \\ *Email koresponden: fifi.nofiyanti17@stptrisakti.ac.id
}

\begin{abstract}
Abstrak
Potensi desa dan alam di Cikolelet Banten perlu ditingkatkan dan diberi pengetahuan untuk pengingkatan SDM. Hal ini didasarkan pada kualitas SDM yang masih kurang pengetahuan, pengalaman, dan percaya diri untuk membangun desanya. Peningkatan kualitas SDM dilakukan dengan mengkaji dan memberikan informasi terkait industri kreatif (kewirausahaan), homestay (penginapan), dan pelayanan prima (prosedur pelayanan yang baik). Kegiatan dilakukan dengan mengkaji potensi desa wisata, kemampuan SDM, dan melihat rumahrumah warga yang akan dijadikan homestay. Melihat beberapa kuliner tradisional khas Desa Cikolelet yaitu emping, susu kambing etawa, jojorong, dan pembuatan welcome drink unuk wisatawan yang hadir. Metode yang digunakan dalam pelatihan ini yaitu presentasi materi, praktik, peninjauan desa, dan peninjauan rumah warga. Peserta dalam kegiatan pelatihan ini berjumlah 30 orang yaitu kepala Desa Cikolelet, para ketua RW, Ketua RT, POKDARWIS, dan warga sekitar. Hasil temuan untuk homestay dari tingkat kelayakan berjumlah $60 \%$, setelah pelatihan dan evaluasi meningkat menjadi 70\%, kebersihan $10 \%$ kemudian meningkat menjadi $50 \%$, keinginan masyarakat meningkat menjadi 30\%, dan keindahan 30\%. Hasil dari pelatihan industri kreatif, masyarakat memiliki kemasan produk yang bernilai jual untuk promosi dan oleh-oleh khas Desa Cikolelet. Pelayanan prima masyarakat dalam melayani wisatawan yang berkunjung meningkat dengan adanya pembuatan paket wisata dan mengantarkan wisatawan ke lokasi wisata. Lokasi yang dijadikan track wisatawan yaitu peternakan kambing etawa, puncak Pillar, puncak Cibaja, air terjun Lawang.
\end{abstract}

Kata kunci: kualitas, SDM, Desa Cikolelet

\begin{abstract}
The potential of villages and nature in Cikolelet Banten needs to be improved and given knowledge for the improvement of human resources. It is based on the quality of human resources who are still lacking the knowledge, experience, and confidence to build their village. Increasing the quality of human resources is done by reviewing and providing information related to creative industries (entrepreneurship), homestay (inn), and excellent service (good service procedures). Activities are conducted by assessing the potential of tourist villages, human resources capabilities, and see the homes of residents who will be homestay. See some traditional culinary Cikolelet Village is emping, goat milk etawa, jojorong, and making welcome drink for tourists who attend. The methods used in this training are material presentation, practice, village review, and citizen house review. Participants in this training activity amounted to 30 people namely the head of Cikolelet Village, the chairman of $R W$, Chairman of RT, POKDARWIS, and local residents. The findings for the homestay of the feasibility rate amounted to $60 \%$, after training and evaluation increased to $70 \%$, cleanliness $10 \%$ then increased to $50 \%$, community demand increased to $30 \%$, and $30 \%$ beauty. The result of creative industry training, the community has a product packaging that is worth selling for promotion and souvenirs typical of Cikolelet Village. The excellent service of the community in serving the tourists who visit increased with the existence of the package tour and deliver tourists to tourist sites. The location used as a tourist track that is etawa goat farm, Pillar peak, peak Cibaja, Lawang waterfall.
\end{abstract}

Keywords: quality, human resources, Cikolelet Village

Format Sitasi: Sulartiningrum S., Nofiyanti F., Fitriana R. (2018). Pelatihan Peningkatan Kualitas SDM Bidang Pariwisata di Desa Wisata. Jurnal SOLMA, 7(2), 176-181. Doi: http://dx.doi.org/10.29405/solma.v7i2.2228.

Diterima: 21 Januari 2018 | Revisi: 20 September 2018 | Dipublikasikan: 30 Oktober 2018 


\section{PENDAHULUAN}

Wilayah desa di beberapa daerah sudah mulai mengembangkan desanya menjadi desa wisata. Berbagai upaya dilakukan untuk membentuk masyarakat desa yang sadar wisata untuk membangun desanya. Pemerintah Desa Cikolelet Serang Banten juga ikut andil dalam pengembangan masyarakat untuk membangun desa wisata. Cikolelet sudah termasuk dalam pengembangan desa wisata, sehingga sudah terbentuknya Pokdarwis. Namun, masih banyak yang perlu dilakukan untuk mengembangkan desa wisata Cikolelet.

Sumber daya manusia (SDM) adalah potensi yang terkandung dalamdiri manusia untuk mewujudkan peranannya sebagai makhluk sosial yang adaptif dan transformatif yang mampu mengelola dirinya sendiri serta seluruh potensi yang terkandung di alam menuju tercapainya kesejahteraan hidup dalam tatanan yang seimbang dan berkelanjutan.

Hasibuan (2003), pengertian sumber daya manusia (SDM) adalah kemampuan terpadu dari daya piker dan daya fisik yang dimiliki oleh individu. Pelaku dan sifatnya dilakukan oleh keturunan dan lingkungannya, sedangkan prestasi kerjanya dimotivasi oleh keinginan untuk memenuhi kepuasannya (kebutuhannya).

Desa Cikolelet sedang giat mengembangkan potensi wisata desanya dengan destinasi wisata unggulan Gunung Pillar dan Gunung Cibaja. Gunung Pillar menawarkan wisata alam yang indah dan alami dengan pemandangan yang eksotis background Gunung Karang Pandeglang. Rute untuk menuju ke Gunung Pillar terbilang mudah. Pengunjung dari Cilegon atau Serang dapat melewati jalan raya Anyer, setelah melewati kawasan wisata Pantai Anyer tepatnya setelah Masjid Al-Kautsar Cinangka sekitar 50 meter ada belokan ke kiri menuju ke perbukitan. Pengunjung tidak akan banyak menemui kesulitan karena banyak penunjuk arah yang dipasang oleh pengelola wisata Gunung Pillar Serang untuk lebih memudahkan pengunjung menuju lokasi.

Gambaran desa wisata Cikolelet yang sudah dirancang oleh pemerintah dan masyarakat sadar wisata tersebut sudah semakin meningkat. Namun, pihak pemerintah masih memiliki permasalahan berkaitan dengan SDM dan cara mengelola desa wisata Cikolelet. Berdasarkan survei yang dilakukan dan kerjasama antara tim pengabdian dengan mitra. Ditemukan adanya beberapa permasalahan mitra, akhirnya tim pengabdian masyarakat mengadakan pengabdian masyarakat berkaitan dengan pelatihan peningkatan kualitas SDM bidang pariwisata di desa wisata Cikolelet Serang Banten.

\section{MASALAH}

Mengacu pada analisis situasi di atas, identifikasi dari permasalahan mitra adalah: 
1. Pengelolaan produk dan paket wisata di desa Cikolelet

2. Pengelolaan home stay di desa Cikolelet

3. Pembawa acara dalam kegiatan seni dan budaya di desa Cikolelet

4. Pengelolaan industri kreatif di desa Cikolelet

\section{METODE PELAKSANAAN}

Metode pelaksanaan pada kegiatan pengabdian masyarakat ini dengan menggunakan beberapa cara yaitu perencanaan, pelaksanaan, dan evaluasi. Adapun penjelasannya sebagai berikut.

1. Perencanaan

Tim mengurus perizinan kepada pihak masyarakat dan pemerintahan Desa Cikolelet serba membuat kerjasama mitra. Pihak pemerintah Desa Cikolelet juga memberikan undangan resmi untuk memberi pelatihan pada masyarakat desa dan Pokdarwis Cikolelet.

2. Pelaksanaan

Tim dosen ke lokasi pengabdian masyarakat di Desa Cikolelet. Mempersiapkan materi penyuluhan dan membagikan informasi berkaitan dengan peningkatan SDM bidang pariwisata.

3. Pendidikan Masyarakat: melakukan kegiatan ditujukan untuk masyarakat Desa Cikolelet yaitu pelatihan (in-house training), penyuluhan yang bertujuan meningkatkan pemahaman serta kesadaran, dan peningkatan kualitas SDM.

4. Evaluasi

Melakukan evaluasi bersama mitra pengabdian masyarakat dan tim pengabdian. Memberi kesempatan tanya jawab dan membantu mitra pengabdian menjawab permasalahan yang mereka hadapi. Tim pengabdian melakukan evaluasi diri tentang kegiatan yang telah dilaksanakan. Agar kegiatan pengabdian masyarakat selanjutnya dapat berjalan dan dilaksanakan lebih baik lagi.

\section{PEMBAHASAN}

Hasil pengabdian masyarakat yang telah dilaksanakan di Desa Cikolelet pada tanggal 5-6 Mei 2018 sebagai berikut: Pada Presentasi Pertama : Sebelum presentasi dilaksanakan, tim bertanya kepada masyarakat tentang pencapaian yang sudah didapat dari terbentuknya desa wisata Cikolelet. Masyarakat menyajikan makanan khas desa yaitu jejorong, kue kontol 
sapi, dan gemblong. Namun mereka belum memiliki minuman khas yang dijadikan welcome drink untuk wisatawan. Presentasi pertama ini menjelaskan tentang industri kreatif yang dapat dikembangkan dan kemasan produk yang cocok untuk makanan khas Cikolelet. Awalnya masyarakat desa belum membuat kemasan produk untuk dijual dan merk produknya. Pada presentasi pertama menjelaskan tentang: 1) Industri kreatif, 2) Kewirausahaan, 3) Memulai Wirausahaan, 4) Kemasan produk, dan 5) Memasarkan produk. Produk yang disediakan oleh masyarakat desa dijadikan contoh dengan memberi kemasan yang cocok sebagai produk kuliner yang dapat dijual. Tim memberi contoh produk dan membuat merk produk. Masyarakat dan tim pengabdian diskusi untuk memberi kemasan dan harga yang tepat untuk produk khas desa Cikolelet yaitu susu kambing etawa, emping, kue jejorong, kontol sapi, dan gemblong. Hasil yang diperoleh setelah pelaksanaan pengabdian ini, masyarakat dapat membuat kemasan yang cocok untuk produk yang akan dipasarkan untuk wisatawan dan tamu yang datang.

Selanjutnya Pada Presentasi Kedua mengenai pengelolaan homestay yang dijadikan penginapan untuk wisatawan. Tim melakukan observasi ke rumah-rumah masyarakat desa Cikolelet untuk melihat kelayakan homestay yang akan dijadikan penginapan untuk wisatawan. Pada presentasi kedua menjelaskan tentang: 1) Pengertian homestay, 2) Kriteria homestay, 3) Produk homestay, 4) Pengelolaan homestay, 5) Pelayanan homestay dan 6) Fasilitas pendukung homestay. Penyampaian materi tersebut sekaligus mempraktikkan cara penataan homestay yang baik dan sesuai standar. Masyarakat antusias untuk mengikuti kegiatan tersebut, karena dengan adanya homestay untuk wisatawan, maka menambah ekonomi masyarakat desa. Setelah dilakukan survei dan pelatihan, maka tim mengklasifikasikan hasil kesiapan homestay masyarakat desa dari segi: kelayakan, keindahan, kebersihan, dan keinginan. Berikut ini diagram lingkaran. 


\section{Tingkat Kesiapan Homestay Masyarakat Desa Cikolelet}

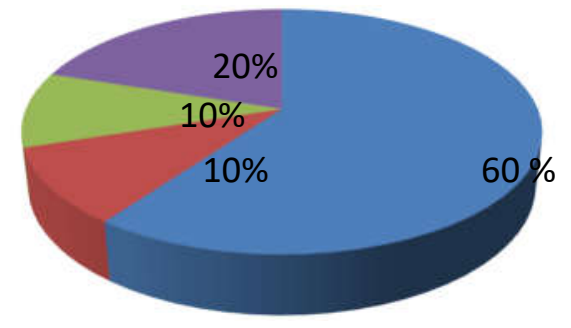

Kelayakan

Keindahan

Kebersihan

Keinginan

Gambar 1. Tingkat Kesiapan Homestay Masyarakat Desa Cikolelet

Pada Presentasi Ketiga dalam pelatihan SDM yaitu tentang pelayanan prima. Kesiapan produk wisata dan alam yang memadai tidak dapat berjalan dengan baik tanpa adanya pelayanan prima dari masyarakat pelaku wisata. Masyarakat diberi pelatihan tentang cara melayani wisatawan yang datang ke desa Cikolelet, hal ini disampaikan agar wisatawan yang datang tidak merasa kecewa dan akan kembali lagi ke desa tersebut. Pada presentasi kedua menjelaskan tentang: 1) Konsep pelayanan prima, 2) Unsur service, 3) Sikap mental pelayanan prima, 4) Kepuasan pelanggan, dan 5) Sikap menghadapi pelanggan. Adanya pelatihan pelayanan prima membuat masyarakat peserta kegiatan ini menjadi termotivasi untuk memenuhi keinginan wisatawan. Di bawah ini merupakan hasil produk yang dihasilkan :

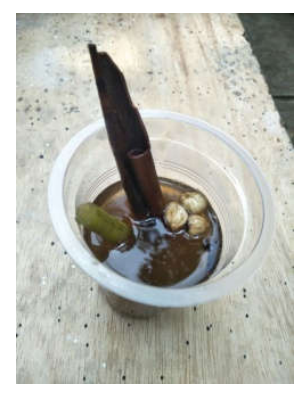

Gambar 2. Welcome drink wisatawan

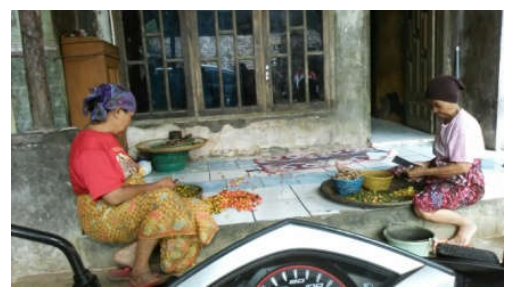

Gambar 3. Masyarakat membuat emping dan hasilnya diberi kemasan 
Melaksanakan follow up setelah satu minggu kegiatan yaitu sebagai berikut:

Hal-hal yang ditemukan setelah pelaksanaan kegiatan,

1) Homestay sudah tertata rapi dan kebersihan sudah dijaga dengan baik

2) Pengemasan produk susu kambing etawa sudah dilaksanakan, namun belum diberikan merk dan nama desa Cikolelet

3) Pengemasan emping sudah dilaksanakan, namun belum diberikan merk dan nama desa

4) Pelayanan prima masyarakat sudah dilaksanakan, terlihat dari sikap masyarakat yang langsung melayani dan mengantarkan wisatawan ke lokasi wisata yang terdapat di desa Cikolelet.

\section{KESIMPULAN}

Kesimpulan dari pengabdian masyarakat ini yaitu usaha dalam peningkatan kualitas SDM di Desa Wisata Cikolelet menjadi perhatian dan fokus pencapaian kepala desa dan tim abdimas. Dengan adanya penyuluhan ini terdapat beberapa peningkatan terlihat dari produk industri kreatif yang telah dikemas menarik, pelayanan prima masyarakat kepada wisatawan, dan homestay yang layak untuk dijadikan penginapa wisatawan. Agar dapat merasakan kehidupan di desa Cikolelet.

\section{UCAPAN TERIMA KASIH}

Kami mengucapkan terima kasih kepada Puslit dan Abdimas STP Trisakti sebagai penyandang dana kegiatan pengabdian masyarakat. Terima kasih kepada Ketua Sekolah Tinggi Pariwisata Trisakti yang mendukung kegiatan ini. Terima kasih kepada Kepala Desa Cikolelet Serang Banten, Bapak Ojat Darojat, POKDARWIS, dan masyarakat desa Cikolelet.

\section{DAFTAR PUSTAKA}

Hasibuan, Malayu. (2003). Manajeman Sumber Daya Manusia. Jakarta: Bumi Aksara.

(C) 2018 Oleh authors. Lisensi Jurnal Solma, LPPM-UHAMKA, Jakarta. Artikel ini bersifat open access yang didistribusikan di bawah syarat dan ketentuan Creative Commons Attribution (CC BY) license (http://creativecommons.org/licenses/by/4.0/). 